\title{
ANATOMY OF THE PALM RHAPIS EXCELSA, VI. ROOT AND BRANCH INSERTION
}

\section{P. B. Tomlinson ${ }^{1}$ and M. H. Zimmermann}

IN PALMS, as in all woody monocotyledons without secondary vascular tissues, there are limitations to the method by which a lateral organ can be attached to the parent axis so as to make an effective vascular union. Schoute has discussed this problem at a morphological level in a series of papers on branching in Pandanaceae, Palmae, and woody Liliiflorae (e.g. Schoute, 1903; 1918; see also Tomlinson, 1964). Anatomical details, however, still remain undescribed. In the preceding paper in this series (Tomlinson \& Zimmermann, 1968) two distinctive methods of branchaxis union were described in relation to inflorescence. On the one hand, the inflorescence axis is basally supplied from the main axis by numerous bundles which diverge from dorsal leaf traces, together with bundles which are attached directly to peripheral vertical bundles. On the other hand, branching within the inflorescence itself involves a simple redistribution of existing vascular bundles between parent axis and branch. It is obvious that although these two types of branch are morphologically equivalent, they must develop differently. However, we have not yet investigated inflorescence development. To complete the study of vascular continuity the present article describes the anatomy of root and branch insertion.

Although these constructional aspects of palms are of fundamental physiological significance, previous investigation has been limited. Von Mohl (1824) and Karsten (1847) made some general observations without describing anatomical details. Mangin (1882) in a notable paper, described various methods of attachment of roots to parent axis in monocotyledons, including a number of palms. Drabble (1904) dealt specifically with the same problem in palms in his lengthy survey of the general anatomy of palm roots. Our own observations on Rhapis have confirmed the findings of these earlier botanists.

\section{METHODS}

Attachment of root and vegetative branch has been revealed to a large extent incidentally during analyses of rhizome and seedling axis. Methods of serial analysis using microcinematography have been described fully in several previous articles (Zimmermann \& Tomlinson, 1965; 1966; $1967 \mathrm{~b})$. In addition, continuous series of sections through root insertions

${ }^{1}$ Research by P. B. Tomlinson on the anatomy of palms is supported by National Science Foundation Grant GB-5762-X. 
(in both longitudinal and transverse planes) and the insertion of a branch at the base of an erect shoot were specially cut and analyzed by the same methods. Photographs which form Figs. 1-9 were made from these additional series of sections.

\section{MORPHOLOGY}

The distribution of adventitious roots and lateral vegetative branches on seedlings, rhizomes, and at the base of the aërial stem has been described and illustrated in the second and third articles of this series (Tomlinson \& Zimmermann, 1966a, b). Briefly, roots are abundant and closely crowded on the seedling axis, widely and irregularly spaced on the rhizome and again numerous at the base of erect shoots; vegetative branches develop either from buds in the axils of transitional leaves on the juvenile axis or at the base of erect shoots. Buds may grow out (usually in order of their age) into rhizomes but many are strongly inhibited, persisting as reduced structures within the protective, somewhat woody prophyll. The subsequent account refers largely to the attachment of roots on rhizomes and of branches to the base of erect shoots. Their attachment to seedlings is briefly commented upon (cf. also Tomlinson \& Zimmermann, 1966b).

\section{ROOT ATTACHMENT}

Roots originate endogenously, rupturing the surface of the stem and modifying its peripheral tissues (FIG. 2). There is a discontinuity between surface tissues of root and stem. The epidermis and wide sclerotic layers of the outer cortex of the root penetrate deeply into (more strictly, differentiate first within) the stem cortex. Cortex of root and stem, however, are continuous. The root endodermis ends blindly in the outer cortex of the stem. Root development also locally stimulates expansion and some division of ground parenchyma cells in the outer part of the central cylinder in such a way that peripheral vascular bundles bulge outwards (FIG. 2).

In a transverse section of the root, close to its insertion (FIG. 1), a peripheral system made up of the normal polyarch xylem and phloem strands can be distinguished from an irregular series of medullary strands which include metaxylem only. These two systems are attached somewhat differently and may be described separately. It must be emphasized initially that no root traces end blindly.

Peripheral system. Peripheral xylem and phloem strands of the root may become attached independently of each other. More commonly the two tissues form discrete vascular strands (root traces) uniformly sheathed by short, thin-walled fibers with a common attachment to one stem bundle (FIgs. 3 \& 4). However, root traces commonly divide into two strands, each with its own xylem and phloem. The vascular strands of this peripheral root trace complex fan out tangentially and make contact with peripheral bundles of the stem. For a vigorous root this tangential spread 


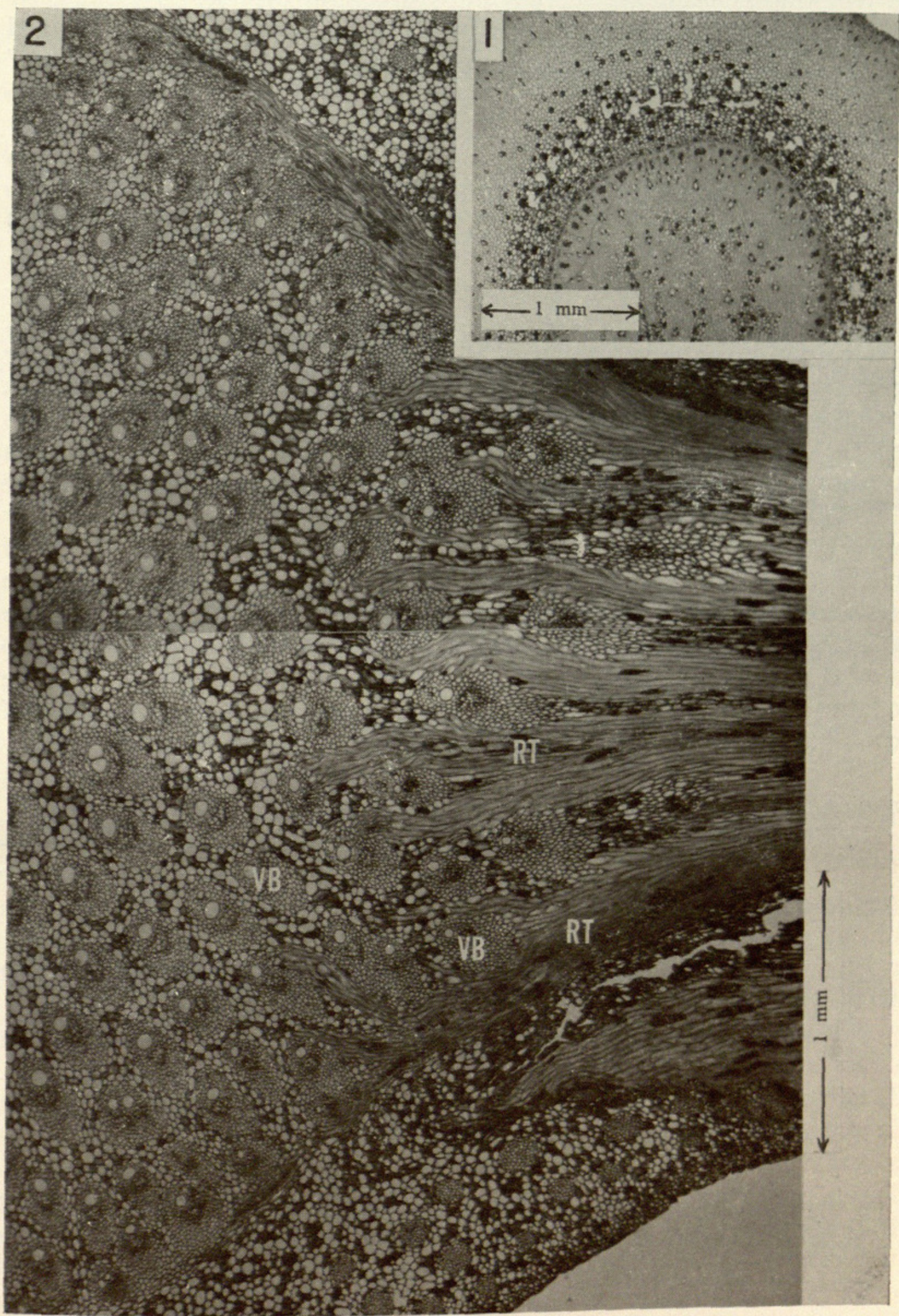

FIgs. 1 and 2. Root insertion in Rhapis excelsa. FIG. 1. Transverse section of root close to its insertion. FIG. 2. Transverse section of rhizome, including root insertion, in approximate median longitudinal section. RT - root trace; VB - vertical bundle of rhizome. 
may be up to one-half the total circumference of the central cylinder (FIg. 2). Close to the root insertion some of the root traces (or branches of root traces) penetrate shortly into the central cylinder to make their attachment. Otherwise traces run in the boundary between cortex and central cylinder. They have been recognized as frequent "girdling traces" in the rhizome (Tomlinson \& Zimmermann, 1966a, p. 255), remote from the root attachment.

Medullary system. Each strand consists of a single wide metaxylem vessel surrounded by a fibrous sheath. The strands penetrate directly into the central cylinder of the rhizome and are attached to peripheral vertical bundles (Figs. 2; 5 \& 6).

Vascular connection. It is not usually possible to see direct continuity between xylem of root trace and stem bundle in a single section, but only in a continuous series of thin sections. The xylem vessel of the root trace breaks up into an aggregate of narrower elements which run parallel to the stem bundle (Figs. $3 \& 5$ ). The distal elements of this cluster are applied to the metaxylem vessel of the stem bundle. This terminal cluster of root trace elements frequently spreads, often nearly 180 degrees, around the circumference of the stem vessel, so making a very wide contact. The metaxylem of the stem bundle is not usually itself modified. This contrasts with vessel-to-vessel contact in the leaf-trace system of the stem, e.g. between bridges and vertical bundles, where bridge attachment induces a characteristic break-up of the metaxylem into several narrow elements. This is the probable result of a difference in the relative time of differentiation of vessels in the two contrasted types of contact.

Phloem to phloem contact in the peripheral system is usually more direct and can often be seen in a single section (e.g. Fig. 3 ).

In the attachment of a mature root, traces are uniformly and fully differentiated throughout their length. Many roots, however, abort or are suppressed. Traces from these root buds connect with the vascular system of the stem. These traces are fully differentiated proximally (at their attachment to the stem) but remain in a procambial state distally (at their attachment to the undeveloped root).

The deep penetration of traces was described by Mangin (1882) as a characteristic feature of root attachment in Palmae and Pandanaceae. Drabble (1904) confirmed these observations on the palms and noted that in many species with larger roots separate strands or aggregates of separate strands may persist into the root well beyond its insertion (see also Tomlinson, 1961, pp. 49-50). In Rhapis the deep penetration of central root traces is particularly noticeable in the seedling. Here they contribute extensively to the anastomosing bridge system which characterizes this part of the stem (Tomlinson \& Zimmermann, 1966b). Undoubtedly, this deep penetration is the result of early root development.

We have not traced the course of the medullary xylem bundles into the root in Rhapis but the observations of Drabble (1904) suggest that these may unite with the peripheral metaxylem strands of the polyarch stele. 

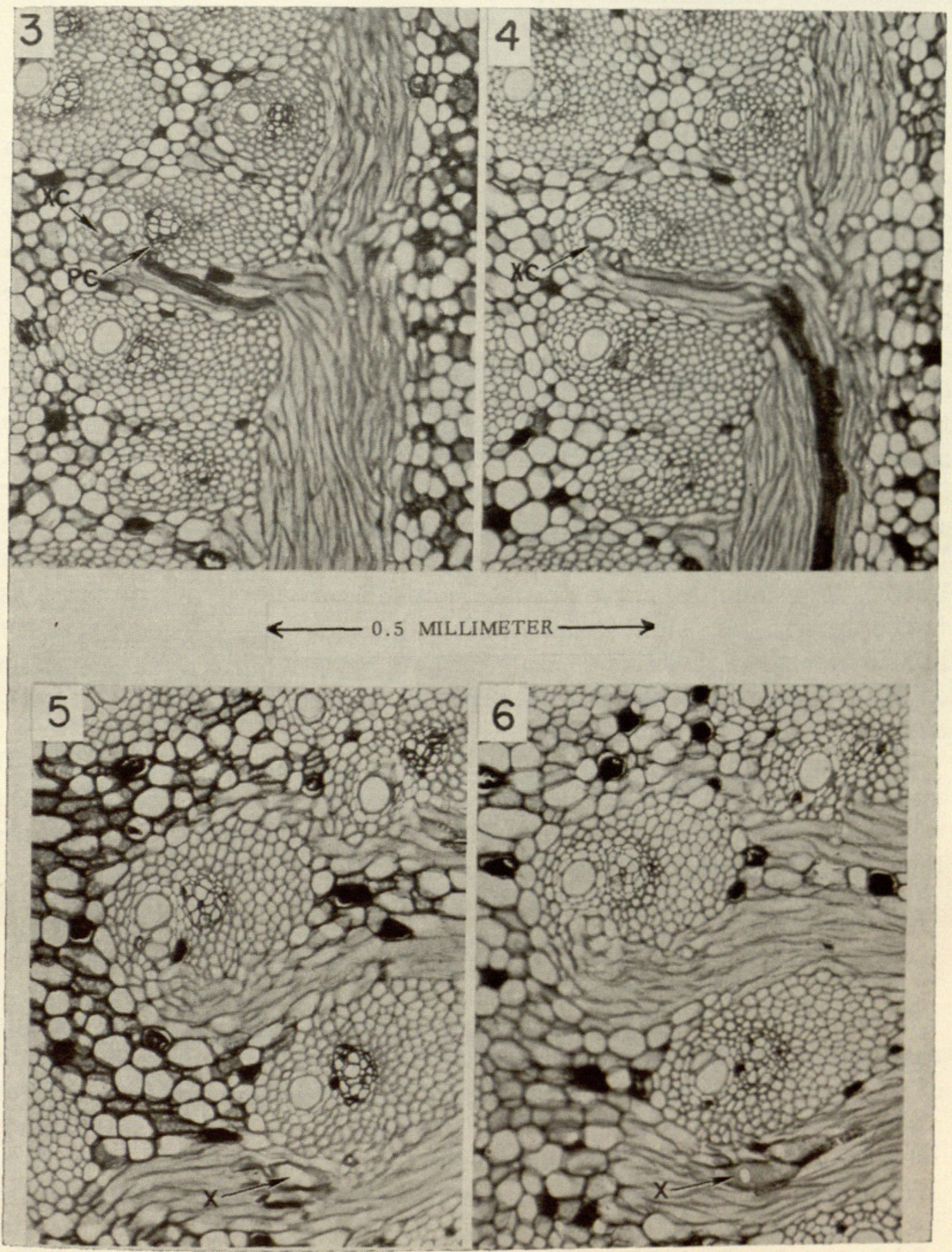

Figs. 3-6. Details of root insertion in rhizome of Rhapis excelsa; attachment of root traces to rhizome bundles. FIG. 3. Attachment of peripheral root trace to peripheral rhizome bundle. Phloem continuous. Fig. 4. Same bundle at a level $40 \mu$ higher, xylem continuous with metaxylem of stem bundle via irregular cluster of tracheal elements. FIG. 5. Attachment of central root trace to rhizome bundle. Cluster of tracheal elements continuous with metaxylem vessel of rhizome bundle. Fig, 6. Same bundle seen $60 \mu$ below Fig. 5. Cluster of tracheal elements here free of vessel in rhizome bundle but continuous into root trace. The root trace in the lower half of both figures shows part of a vessel. PC phloem continuity; XC - xylem continuity; X - xylem. 
However, medullary vessels remain as a feature of the distal parts of Rhapis roots (Tomlinson, 1961).

\section{BRANCH ATTACHMENT}

Vegetative axillary buds which produce branch rhizomes differ from roots in having an exogenous origin. The rhizome itself has a vascular system of discrete strands which are inserted into the parent axis very much like root traces (FIG. 7). Individual branch traces are all alike, each with both xylem and phloem; there are no traces with xylem only, as in the root. The strands run from the branch and anastomose irregularly and at random with the bundles of the parent stem (FIG. 8), often forking distally (FIg. 9). None of them end blindly. Central branch traces penetrate deeply into the stem to make their attachment; peripheral bundles spread markedly around the circumference of the stem forming a distinct layer of vascular bundles between the cortex and the central cylinder (FIg. 7). Vessel to vessel attachment between branch trace and stem bundle is often much more direct than that between root trace and stem bundle. This indicates approximately simultaneous development of vessels in the two strands. However, the contact between branch trace and stem bundle sometimes involves an intermediate plexus of terminal elements as in the root, indicating later development of the branch trace (e.g. Fig. 8).

Many vegetative buds are inhibited but the suppressed primordia still make extensive vascular contacts with the parent stem via branch traces which remain at a procambial stage of development in the bud itself, although the same traces in the axis are fully differentiated.

\section{DISCUSSION}

Physiological significance of vascular continuity. It is obvious that the discrete vascular bundles represent the pathway for translocation of water and nutrients throughout the palm. The present article completes a description of the continuous vascular system in Rhapis. The channels for long distance conduction throughout the palm are now quite evident. Water from the roots passes into the stem via the numerous linkages at the root insertion. A continuous channel along the rhizome and up the aërial stem is afforded by the axial bundle system which links directly with each leaf via leaf traces. Cross-linkage is effected by the frequent bridge bundles associated with outgoing leaf traces. In the aërial stem the helical path of the central bundles further promotes lateral and more uniform distribution of water. Vascular continuity into the inflorescence is provided by inflorescence traces which diverge either directly from the peripheral vertical bundles or as "satellites" from the major leaf traces. In this way the inflorescence links with both peripheral and central bundles. New vegetative branches are also connected directly to the axial system 

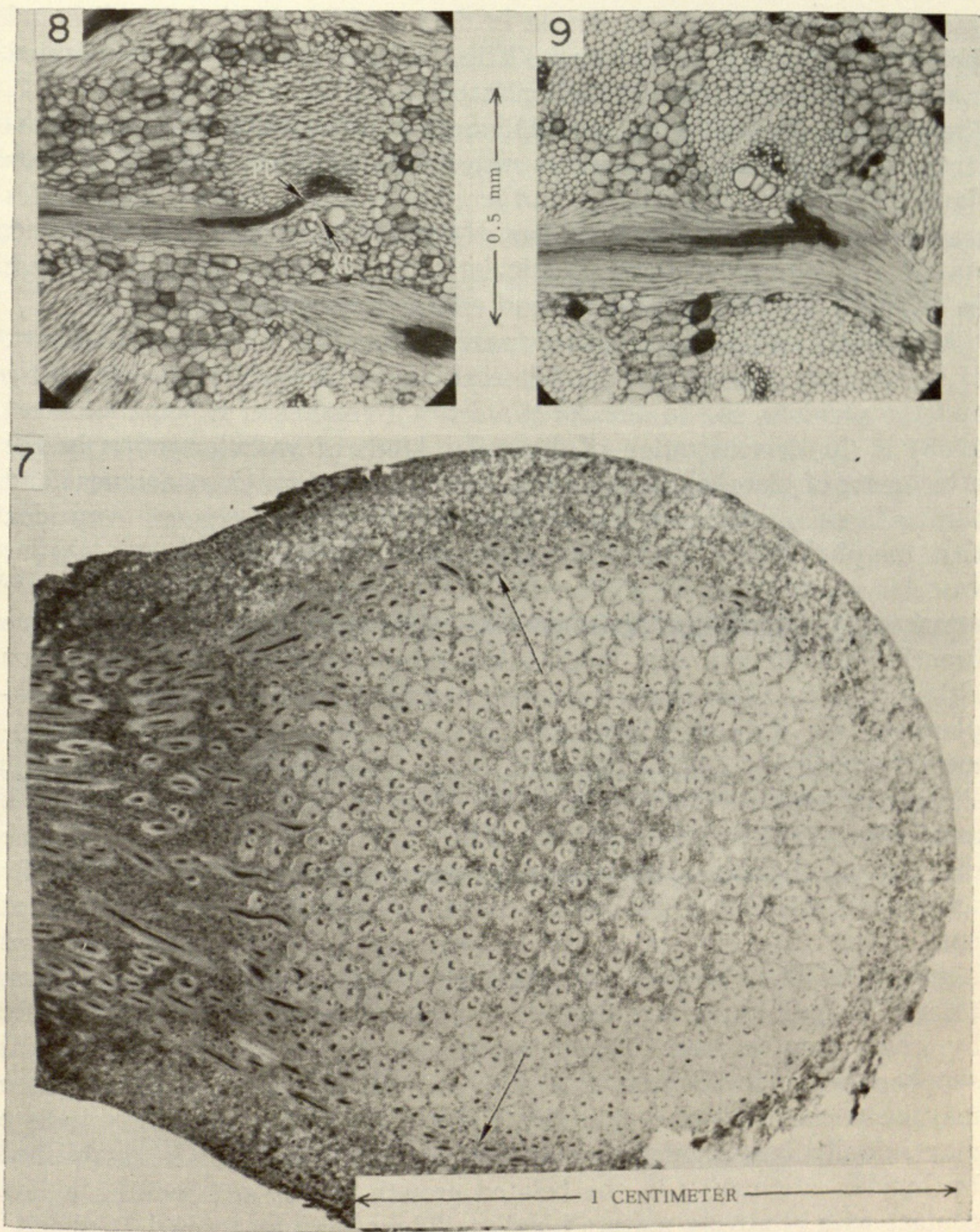

Figs. 7-9. Branch insertion in Rhapis excelsa. Fig. 7. Transverse section of base of erect stem with branch (rhizome) attachment to left. The layer of branch traces between cortex and central cylinder of the parent axis is conspicuous (arrows). FIgs. 8 and 9. Details of attachment of branch traces to bundles of erect stem. FIG. 8. Showing direct continuity of phloem, and xylem continuity via an intermediate cluster of elements. FIG. 9. A forked branch trace. $\mathrm{PC}$ - phloem continuity; XC - xylem continuity.

of the parent stem through which they must derive their water supply until such time as they produce an independent root system.

The pathway from foliage leaves for products of photosynthesis is equally continuous. At the node the downward-descending nutrients may be redistributed in three possible ways. First, they may pass from the leaf 
trace to the vertical bundle, or via bridges to other vertical bundles and thence upwards to the shoot apex. This pathway is clearly demonstrated in our illustration of the developing vascular system in the crown (Fig. 2, Zimmermann \& Tomlinson, 1967a). Second, assimilates may move directly to an axillary inflorescence via satellites. This pathway is very significant and is discussed in further detail below. Third, assimilates may move downwards into the stem. Much of this material is stored as starch in ground parenchyma, particularly in the rhizome, but some must be available for developing roots and additional rhizomes.

Vascular continuity in developmental terms. An important aspect of the analysis of the insertion of lateral organs carried out in this article and the previous one in the Rhapis series (Tomlinson \& Zimmermann, 1968 ) is the demonstration of dissimilar kinds of vascular union in the attachment of morphologically equivalent kinds of branch attachment and similar kinds of union in the attachment of dissimilar organs. Any idea that morphologically equivalent parts must necessarily have a similar vascular supply must be abandoned. Roots and vegetative branches are attached in essentially the same way. The attachment of vegetative branch, inflorescence axis, and inflorescence branch are all dissimilar although in morphological terms these organs are all equivalent. An explanation for these apparent discrepancies must be sought in developmental terms.

We have suggested in a paper in this series in which development of the axial system was described (Zimmermann \& Tomlinson, 1967a), that the distribution of procambial strands in the developing crown can best be understood in terms of competing centers of growth, in which the shoot apex proper, leaf primordia, and inflorescence primordia each represent a growth center. The time of appearance of one growth center in relation to another is of major significance. Centers all receive a vascular supply by which they are fed. Those that appear early receive a procambial supply which is continuous with centers of supply of assimilates. These may be termed "supply" bundles. Centers which appear relatively late may initially lack continuity with existing bundles. This is established by bundles originating in the belated growth center and making a late contact with relatively mature bundles. These may be termed "demand" bundles. It is probably more useful in a physiological sense to speak of developing vascular traces in terms of "supply" and "demand" rather than of traces which grow "towards" or "away from" a growth center (or upwards, or downwards) since this implies a direction of differentiation which may not exist.

Differing types of organ are supplied by one or other of these types of bundle, sometimes by both in combination. Growth centers may, therefore, be categorized developmentally according to their type of vascular attachment to the parent axis. Root primordia and branch primordia arise late in relation to the maturation of the axis. They are clearly connected to the main axis by "demand" bundles which seemingly grow towards existing vascular strands. The vascular tissue of these existing 
strands is at a relatively late stage of maturation and is little influenced by the late attachment of a trace. We have shown how vessel-to-vessel contact from root trace to stem bundle involves a plexus of narrow elements around the vessel of the bundle which otherwise remains little altered. This reflects a late attachment of the trace.

Root and branch primordia on seedlings develop earlier than their counterparts on mature axes. This is indicated by the deeper penetration of root and branch traces into the seedling axis.

Branch and root primordia whose development is inhibited complete a vascular union with stem bundles in such a way that the fully differentiated attached end of each trace is immature distally. It is important to realize that this sequence of maturation is by no means an indication of a "direction" of differentiation.

The shoot apex proper and primordia of branches on the inflorescence axis may serve as examples of growth centers wholly vasculated by "supply" bundles. The latter example is particularly instructive (see Fig. 13, Tomlinson \& Zimmermann, 1968), part of the axial system of "supply" bundles of the inflorescence is simply channeled towards the new growth center represented by the branch primordium.

The insertion of inflorescence on the main axis serves as an example of a union which involves both kinds of vascular attachment. The inflorescence primordium is initiated early. Contact with the developing stem system is established via "supply" bundles in the form of "satellites" which diverge from major leaf traces towards the growth center represented by the inflorescence primordium. Commonly at this stage the inflorescence aborts and remains as a vestigial axillary structure a few millimeters long. The satellite bundles, however, persist as a vascular system out of all proportion to the organ they supply. However, should normal development of the inflorescence continue, the vascular system is necessary and moreover is supplemented by an additional series of "demand" bundles visible as the inflorescence traces directly attached to peripheral stem bundles. These must appear late in inflorescence development because no evidence of them is found in aborted inflorescences.

\section{SUMMARY}

Vascular connection between either a root or a rhizomatous branch, on the one hand, and the main axis, on the other, is effected in essentially the same way. Root or branch traces are attached directly to axial vascular bundles, often penetrating deeply into the stem. An extensive peripheral attachment via girdling traces is also present. No bundles end blindly. The relative times of maturation of main and lateral organ determine the extent and type of connection. This is in turn reflected in the way in which vessel-to-vessel continuity is established, either directly or via an intermediate plexus of tracheal elements. Comparison with types of branching in the inflorescence suggests that the vascular union between main axis and lateral organ must all be understood in developmental 
terms. For this reason morphologically equivalent organs may have different attachments if they develop differently and dissimilar organs may have similar attachments if their development is the same.

\section{ACKNOWLEDGMENTS}

The assistance of Miss Lesley Jackson who prepared all the series of sections on which this study is based is gratefully acknowledged.

\section{LITERATURE CITED}

Drabble, E. 1904. On the anatomy of the roots of palms. Trans. Linn. Soc. Lond. ser. 2. 6: 427-490.

Karsten, H. 1847. Die Vegetationsorgane der Palmen. Abh. Akad. Berlin Physik. 1847: 73-236.

MangIN, L. 1882. Origine et insertion des racines adventives et modifications corrélatives de la tige chez les Monocotylédones. Ann. Sci. Nat. Bot. sér. 6. 14: 216-363.

Mohl, H. von. 1824. De palmarum structura. In: K. F. P. von Martius, Historia naturalis palmarum 1: I-LII. $16 \mathrm{pls}$.

Schoute, J. C. 1903. Die Stammesbildung der Monokotylen. Flora 92: 32-48.

- 1918. Úber die Verästelung bei monokotylen Bäumen. III. Die Verästelung einiger baumartigen Liliaceen. Rec. Trav. Bot. Néerland. 15: 263-335.

Tomlinson, P. B. 1961. Palmae. In: C. R. Metcalfe, ed. Anatomy of the Monocotyledons 2. xv +453 pp. Clarendon Press, Oxford.

- 1964. Stem structure in arborescent monocotyledons. In: M. H. Zimmermann, ed. The formation of wood in forest trees. pp. 65-86. Academic Press, New York.

- \& M. H. Zimmermann. 1966 a. Anatomy of the palm Rhapis excelsa, II. Rhizome. Jour. Arnold Arb. 47: 248-261.

— 1 1966b. Anatomy of the palm Rhapis excelsa, III. Juvenile phase. Ibid. 301-312.

\& 1 1968. Anatomy of the palm Rhapis excelsa, V. Inflorescence. Ibid. 49: 291-306.

Zimmermann, M. H., \& P. B. Tomlinson. 1965. Anatomy of the palm Rhapis excelsa, I. Mature vegetative axis. Jour. Arnold Arb. 46: 160-180.

$-\&-1966$. Analysis of complex vascular systems in plants: Optical shuttle method. Science 152: 72-73.

\& - 1967a. Anatomy of the palm Rhapis excelsa, IV. Vascular development in apex of vegetative aërial axis and rhizome. Jour. Arnold Arb. 48: 122-142.

\& 1 1967b. A method for the analysis of the course of vessels in wood. Bull. Int. Assoc. Wood Anatomists. 1967(1): 2-6.

Fairchild Tropical Garden

MIAMI, FLORIDA 33156

AND

HARVARD UNIVERSITY

Cabot Foundation, Petersham,

Massachusetts 01366 


\section{$2 \mathrm{BHL}$ Biodiversity Heritage Library}

Tomlinson, P. B. and Zimmermann, Martin Huldrych. 1968. "Anatomy of the Palm Rhapis excelsa VI. Root and Branch Insertion." Journal of the Arnold Arboretum 49(3), 307-316. https://doi.org/10.5962/p.324698.

View This Item Online: https://www.biodiversitylibrary.org/item/40867

DOI: https://doi.org/10.5962/p.324698

Permalink: https://www.biodiversitylibrary.org/partpdf/324698

\section{Holding Institution}

Missouri Botanical Garden, Peter H. Raven Library

\section{Sponsored by}

Missouri Botanical Garden

\section{Copyright \& Reuse}

Copyright Status: In copyright. Digitized with the permission of the rights holder.

Rights Holder: Arnold Arboretum of Harvard University

License: http://creativecommons.org/licenses/by-nc-sa/3.0/

Rights: https://biodiversitylibrary.org/permissions

This document was created from content at the Biodiversity Heritage Library, the world's largest open access digital library for biodiversity literature and archives. Visit BHL at https://www.biodiversitylibrary.org. 